\title{
Evaluation from the quality of life in the oral breathers patients
}

\author{
Avaliação da qualidade de vida em pacientes respiradores orais \\ Cristiane Popoaski', Taise de Freitas Marcelino², Thiago Mamôru Sakae ${ }^{3}$, Larissa Martins Schmitz', Luiz Henrique Locks Correa'.
}

1) Academic of Medical School.

2) Doctor, Residency in Otorhinolaryngology - Angelina Caron Hospital - Curitiba - PR, Fellow in Facial Plastic Surgery-Red Cross Hospital - Curitiba - PR. Otorhinolaryngologist Professor at Medical Internship of Medicine Course of UNISUL.

3) Doctor, Residency in Family Health and Community Medicine - HNSC; Master in Public Health - UFSC; PhD in Medical Sciences - UFSC. Professor ofMedicine Course of UNISUL.

Institution: University of South of Santa Catarina - UNISUL.

Tubarão/SC - Brazil.

Mailing address: Cristiane Perini Popoaski - 687 José Acácio Moreira, Av - District: Morrotes - Tubarão / SC - Brazil - Zip-code: $88704-000$ - Telephone: (+55 48) 3622-2039/9161-4004 - E-mail: crispopoaski@gmail.com

Article receivedin 2011 June $15^{\text {th }}$. Article approvedin 2011 September $21^{\text {st }}$.

\section{SUMMARY}

Introduction: The oral breathing is a frequent symptom in childhood and has many alterations that compromise the child physical and cognitive development, negatively influencing from the oral breather, comparing her with the not oral breathers. Method: Cross sectional study, prospective with a sample from 71 patients from 4 to 17 years, being 39 mouth breathers attended by otorhinolaryngologists and 32 patients not mouth breathers as the control group, evaluated as the quality of life through a questionnaire.

Results: The oral breathers presented more nasal problems, with the sleep and food, besides an greater average punctuation for snoring at night $(\mathrm{p}<0,0001)$, when compared to the control group. The prevalence of night snoring in the patients oral breathers was of $87,2 \%$. The high punctuation in the scale of answers meant a worst quality of life.

Conclusion: The syndrome of the oral breather seems to be related to a negative impact in the quality of life, mainly for the nasal problems, with the sleep and eating. Future studies with the application of the same questionnaire have become needed for this to become as capable instrument of evaluation of the life quality from the patients in the matter.

Keywords: mouth breathing, quality of life, snore, pharyngeal tonsil, palatine tonsil.

\section{RESUMO}

Introdução: A respiração oral é um sintoma frequente na infância e exerce diversas alterações que comprometem o desenvolvimento físico e cognitivo infantil,influenciando negativamente na qualidade de vida do paciente.

Objetivo: Avaliar a qualidade de vida do respirador oral, comparando-a com não respiradores orais.

Método: Estudo transversal descritivo, prospectivo com uma amostra de 71 pacientes de 4 a 17 anos, sendo 39 respiradores orais atendidos por otorrinolaringologistas e 32 pacientes não respiradores orais como grupo controle, avaliados quanto à qualidade de vida através de um questionário.

Resultados: Os respiradores orais apresentaram mais problemas nasais, com o sono e alimentares, além de uma maior pontuação média para roncar à noite $(\mathrm{p}<0,0001)$, quando comparados ao grupo controle. A prevalência de roncos noturnos nos pacientes respiradores orais foi de $87,2 \%$. A alta pontuação na escala de respostas significou uma pior qualidade de vida.

Conclusão: A Síndrome do Respirador Oral parece estar relacionada a um impacto negativo na qualidade de vida, principalmente no que se refere aos problemas nasais, com o sono e alimentação. Futuros estudos com a aplicação do mesmo questionário tornam-se necessários para que este possa se tornar um instrumento capaz de avaliar a qualidade de vida dos pacientes em questão.

Palavras-chave: respiração bucal, qualidade de vida, ronco, tonsila faríngea, tonsila palatina. 


\section{INTRODUCTION}

The World Health Organization (WHO), since 1947, defines health as physical well being, psychic, social and not only the disease absence (1).

Among the changes with potential influence in patient's quality of lifeis found in oral breathing. The oral breathing occurs when nasal breathing is substituted by a breathing pattern is supplemented by oral breathing (1,25), during a period longer than six months (1). Generally, the exclusive oral breathing is rare, having in most of the times a mixed pattern of breathing, oral and nasal, in patients in this condition (1).

The oral breathing can be caused by several factorsamong them adenoid hypertrophy, tonsils and turbinates $(3,6)$, deviated septum (if there's nasal obstruction) $(2,3,6)$, allergic rhinitis $(6,7)$, nasal deformities and facials, and,more rarely, foreign body (4). The obstruction of upper airways, in its diverse locations $(2,7)$, constitute the main causes of oral breathing, varying its prevalence according to the individual age. The obstruction of upper airways does not be absolute, since the resistance to the airflow is inversely proportional to fourth potency of the diameter through to air passes $(8,9)$.

Besides being involved in the pathophysiology of obstructive forms of oral breathers, the irreducible hypertrophy of adenoidsand/ or tonsils is considered the primary form of breathing disorders related to sleep, which compromise children's physical and cognitivedevelopment (2).

In infants and preschoolers, the acquired conditions, such as adenotonsillar hyperplasia and cronical inflammatory, are the obstructive causes observed with greater frequency (1), being the adenotonsillar hypertrophyirreducible is considered the primary form of breathing disorders related to sleep, which compromises children's physical and cognitive development. (2). The allergicrhinitis has great importance as oral breathing cause in schooler and teenagers $(1,2)$.

The diagnosis of oral breather patient is essentially clinic, being performed complementary examination to evaluate the lever of airways obstruction and for differential diagnosis, directing the therapeutic approach. The diagnosis and precocious approach of this clinical condition are fundamental to minimize the consequences.

Depending on the duration, the oral breathing can cause functional alterations, structural, pathological, postural, occlusive and behavioral $(1,2,4,10,11)$. The age in the beginning of symptoms, the time of permanence of these till its normalization and the obstruction intensity which influence the installation of the manifestations resulting from mouth (1).

The most common complaints from oral breathers are: nocturnal dyspnea and apnea, to tire easily during physical activities, pain in the back and neck,olfactory and/ or gustatory disturbs $(2)$, halitosis $(1,10)$, dried mouth, to wake up choking during the night, sleeping badly, daytime sleepiness, sneezing, abundant salivation when talking (10), hearing loss and lacrimation (1), among others.

According to the severity of permanence time of this breathing pattern, systemical repercussions can occur, leading to negative consequences in quality of life of these individuals due to the personal impact, physical, psychological and social $(1,3)$. The oral breathers can present a delay in weight and stature; cardiological changes like hypertension, pulmonary hypertension and "cor pulmonale"; lower respiratory disorders with greater cough frequency, obstructive dyspnea and apnea; neuropsychiatric disorders like behavioral alterations (such as, for example, hyperactivity, restless sleep, irritability, difficulty of concentration, reduction on scholar performance, despite of normal intelligence, nocturnal enuresis) $(2-4,10)$, headache, and a tendency to higher frequency of infections (1).

The approach of oral breather must be alwaysmultidisciplinarywhen possible $(1,10)$. It become necessary to the professionals of health area to recognize the oral breather in the beginning of the development of condition, in order to act precociously in a way to minimize the cronical repercussion and improve overall quality of life of these patients.

The oral breather patient presents several changesdue to oral breathing, being children more affected by interference in their growth, development and quality of life. This way, this work was proposedto evaluate the quality of life of oral breather, comparing to non oral breathers.

\section{METHOD}

It was performed a descriptive transversal study through a questionnaire evaluating the quality of life in oral breather patients. The questionnaire was addressed to patient or to his accompanying person when he was unable to answer the proposed questionnaire. It was included in this study patients with age between 4 and 17 years-old attended in otorhinolaringological offices diagnosed of Oral Breather Syndrome which would be submitted to surgery 
of tonsillectomy, adenoidectomy or adenotonsillectom, at city of Tubarao/SC, in the period of 2010 March to 2010 June.

The Project of this study was approved by the Research and Ethics Committee of University of South of Santa Catarina - UNISUL under protocol 09.693.4.01.III.

The data were collected on its own sheet and tabulated in statistical softwareEpidata 3.1 and for analysis the software SPSS (Statistical Package for Social science) version 16.0 .
The data were analyzed by percentage in qualitative variables and measures of central tendency and dispersion in quantitative variables. The qualitative variables were compared, using the chi square test of Pearson, and the differences of mean score differences of dominium of quality oflife questionnaire were tested through test tStudent, in confidence level of $95 \%$.

From the sample of 71 patients, from these: 39 were oral breathers and 32 were of control group (children and teenager without oral breather diagnosis).

\section{Questionnaire}

Name:_ gender: () feminine () masculine

Age:

This is not a test and, thus, there are not right or wrong answers.

Do you have any nasal problem?
() yes
( ) no
() I cannot answer

I- Do you feel disturbed with your breathing?

2- Do you use to be with your nose blocked? $\begin{array}{lllll}1 & 2 & 3 & 4 & 5\end{array}$

3- Do you use to sneeze frequently?

$\begin{array}{llll}2 & 3 & 4 & 5\end{array}$

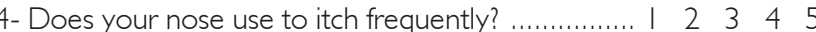

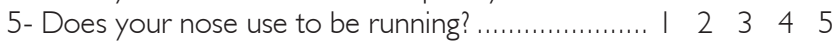

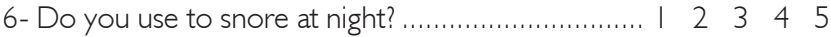

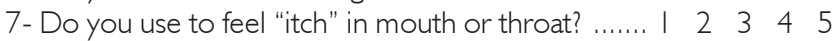

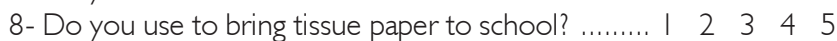

Do you have any trouble with sleep?
() yes
( ) no
() I cannot answer

I- The sleep use to be calm? $\begin{array}{lllll}1 & 2 & 3 & 4 & 5\end{array}$

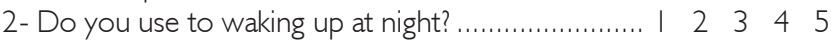

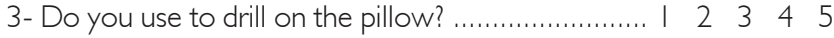

4- Do you use to complaint about sleep during the day? I 23445

5- Do you use to sleep with mouth open? .............. I 2

6- Have you ever stopped breathing while sleeping? I $22 \quad 3 \quad 4 \quad 5$

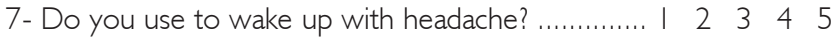

8- Do you use to peeing on bed? ........................... | $\quad 2 \quad 3 \quad 4 \quad 5$

9- Do you use to grind the teeth? .......................... | | 23445

I0- Do you use to wake up with dried mouth? ........ | $\quad 2 \quad 3 \quad 4 \quad 5$

Some eating problem? () yes ( ) no

I-Do you use to eat well? ...................................... | 2345

2- Do you use to chew well the food? .................... । $\quad 2 \quad 3 \quad 4 \quad 4$

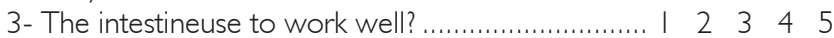

4- Do you use to choke during the meal? ............... | I 23045

5- Do you use to drink during the meal? ................. | 23234

6- Do you use to feel breathless during the meal? .... I $122 \quad 3 \quad 4 \quad 5$

7-Do you use to feel sore throat? ......................... | 23445

Odontology / Esthetics

I- Have you ever gone to the dentist? ( ) yes ( ) no

2- Have you ever had caries? () yes () no

3- Do you use to brush the teeth at least twice a day? .... I 2345

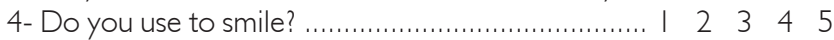

5- Do you use to like of you dental appearance? ...... I $\quad 2 \quad 3 \quad 3 \quad 4 \quad 5$

6- Would you like to use dental braces? ( ) yes ( ) no
Education

I- Have you ever been in school? () yes () no

2- In which grade are you? ( ) $2^{\text {nd }}$ period () $3^{\text {rd }}$ period

() $\left.\right|^{\text {st }}$ grade of fundamental () $2^{\text {nd }}$ grade

() $3^{\text {rd }}$ grade ( ) $4^{\text {th }}$ grade () $5^{\text {th }}$ grade () $6^{\text {th }}$ grade () I don't know

3- In which shift do you attend? ( ) morning ( ) intermediate

() afternoon

4- Any problem at school? () yes ( ) no

5- Do you keep up the classes at school? ............... I 22345

6- Do you used to present difficulty in learning? ....... I $\quad 2 \quad 3 \quad 4 \quad 45$

7-Do you used to have good memory? .................. | 23234

8-Do you used to like going to school? ................... | $\mid \begin{array}{llll}2 & 3 & 4 & 5\end{array}$

9- Do you practice Sport out of the school time?

() no () yes

Communication Characteristics

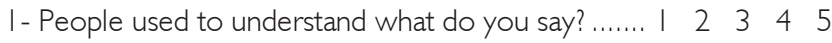

2- Do you used to hear well? .................................. | 2

3- Do you used to get tired when speaking? ............ । 23234

Atopy

I- Do you use to feel itch in your eyes? .................... I $\quad 2 \quad 3 \quad 4 \quad 5$

2- Have you ever wheezed?

( ) yes ( ) no ( ) I cannot answerAge $\left.\right|^{\text {st }}$ crisis:

3- Still wheezes?:( ) yes ( ) no Number of crisis of last year?

4- Do you use to cough or get tired when playing or running? ................................................. | 23234

5- Do you use to cough at night? ........................... । $\quad 2 \quad 3 \quad 4 \quad 5$

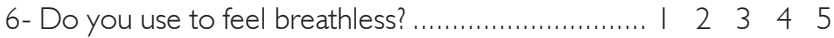

7- Do you use to have itchy skin? .......................... | 20345

NO / NUEVERONCE IN A WHILE ALWAYS

I $23 \quad 3 \quad 4 \quad 5$

ALMOST NEVER ALMOST ALWAYS 
The quality of life of oral breather patients were evaluated by a questionnaire constituted of structured questions, in which were created seven fields from dividing the questions adapted from Ribeiro (1). The fields indentified were: nasal problems, Odontology, sleep, eating disorders, education, communication and atopy. It was associated an ordinal value to the sequential answer scale of 1 for "no/ never", 2 for "almost never", 3 for "once in a time", 4 for "almost always", 5 for "always", being the higher score referred to a worst quality of life. The questions number 1 of field sleep quality, 1-3 of nutrition, 3-5 of Odontology, 5,7,8 of educationand 1,2 of communication had its scored reversed in order to keep coherency in sum of the final score.

The quality of life scale creation from the questionnaire was done in the following way:

- Field of nasal problem (P) was structured by sum of questions P1 to P8 of questionnaire with score varying from 8-40;

- Field of trouble sleeping (S), it had reversed scoring forS1 and sum of the questions S1to S10 varying its score from 10-50;

- Filed of nutrition (AL) it was performed reversed scoring for AL1 to AL3, with the sum of the questions AL1 to AL7 with scoring varying from 7 to 35;

- Field of Odontology (O) occurred the sum of the questions $\mathrm{O} 3$ to 06 , with reversed scoring for $\mathrm{O} 3$ to $\mathrm{O} 5$ and the variable $\mathrm{O} 6$ when answered as yes $=5$ scoresand no $=1$ score, with scores varying between 4 and 20;

- Field of education(E), occurred the sum of questions E5 to E8 the questions O5-O8 had its score reversed, the scoring varied from 4 to 20 ;

- Field of communication (C), was structured by the sumo f questions $\mathrm{C} 1$ to $\mathrm{C} 3$, with reversed scoring in C1 and $\mathrm{C} 2$ and scoring varying from 3 to 15.

- Atopy field (AT), occurred to the sumof questions AT1, AT3-AT7, the question AT3 received 05 scores to answer yes and 1score for answer no, with scoring varying from 5 to 25 .

The total scoring varied from 41 to 205, being the highest scoring the worst quality of life, according to the proposed scale of questionnaire (Table 1 ).

\section{RESULTS}

The sample was composed of 39 cases (oral breathers) and 32 controls (non oral breathers), at age of between 4 and 17 years-old.There were no differences statistically significativeamong the cases and controls according to gender, access to Odontology and negative perception of dental appearance, education and scholar troubles. The controls were, in average, 1,8 year oldest than the cases.
The oral breathers presented significantly nasal problems, sleeping troubles, eating troubles, practiced fewer sports and presented asthma with greater frequency (wheezing).

In field of nasal problems, the average score was significantly higher in the oral breather (average $=27,21$ ), comparing to controls (average $=14,63$ ), as can be seen on Table 2.

In Odontology field $(\mathrm{p}=0,612)$ and education $(\mathrm{p}=0,535)$, it was not found significantly differences between cases and controls (Table 2).

In sleeping trouble field, the average scoring was significantly greater in oral breathers (average $=30,13$ ), comparing to controls (average=17,09). In the same way, in the field of nutrition disturb the average score was significantly greater in the group of oral breather (average $=18,49)$, comparing to controls (average $=14,16$ ) (Table 2).

In field of communication characteristics, the average scoring was significantly greater in oral breathers (average $=5,92$ ), comparing to controls (average $=4,31$ ). In field related to atopy, it was found greater scoring in oral breathers (average $=15,36$ ), when compared to control group (average $=10,59$ ) (Table 2 ).

By the frequency in answer scale the oral breathers presented greater average scoring in snoring at night ( $p<0,0001$ ), sleeping with mouth opened, choking during when having meal and feel breathless. The prevalence of nocturnal snoring in patients oral breather was of $87,2 \%$, setting up a risk 27 times greater of snoring when compared to the controls ( $\mathrm{RP}=27,89$; IC95\%: 4,03 - 192,74; $\mathrm{p}<0,0001$ ).

It was observed an average scoring in total of fields of 113,35 to oral breathers and 74,91 for control group,characterizing worst quality of life in oral breather group (Table 2).

\section{DISCUSSION}

From seven fields evaluated, it was observed that the trouble sleeping field and nasal problem were the fields with greater scoring, suggesting that these fields can bring greater negative repercussion in quality of life during evaluation of oral breather patients (12-23), and nasal problems during evaluation of oral breather $(24,25)$. In this present study, the prevalence of troubles with sleep in oral breather were almost three times greater, when compared to the study of Ribeiro $(37,7 \%)$ in a sample of 75 oral breathers (1). 
Table I. Sociodemographic characteristicsevaluated between the cases (oral breathers) and the controls (non oral breathers).

\begin{tabular}{|c|c|c|c|}
\hline Variable & case n (\%) & control n (\%) & $\mathrm{p}$ \\
\hline $\begin{array}{l}\text { Gender: } \\
\text { Masculine } \\
\text { Feminine }\end{array}$ & $\begin{array}{l}15(38,5 \%) \\
24(6 \mid, 5 \%)\end{array}$ & $\begin{array}{l}13(40,6 \%) \\
19(59,4 \%)\end{array}$ & I \\
\hline Age (average +DP) & average $=7,05(+-3,67)$ & average $=8,84(+-3,45)$ & 0,039 \\
\hline Nasal problem & $35(89,7 \%)$ & $5(15,6 \%)$ & $<0,000$ \\
\hline Sleeping trouble & $36(92,3 \%)$ & $3(9,4 \%)$ & $<0,0001$ \\
\hline Eating problem & $19(48,7 \%)$ & $5(15,6 \%)$ & 0,005 \\
\hline Odontology: & $30(76,9 \%)$ & $30(93,8 \%)$ & 0,096 \\
\hline Have you ever been to dentist? & $19(48,7 \%)$ & 14(43,8\%) & 0,805 \\
\hline Have you ever had caries? & I $5(38,5 \%)$ & $8(25 \%)$ & 0,289 \\
\hline \multicolumn{4}{|l|}{ Would you like to use braces? } \\
\hline Education: & $36(92,3 \%)$ & $32(100 \%)$ & 0,277 \\
\hline Have you ever been at school? & $8(20,5 \%)$ & $2(6,2 \%)$ & 0,269 \\
\hline \multicolumn{4}{|l|}{ In which grade are you? } \\
\hline \multicolumn{4}{|l|}{$2^{\text {nd }}$ period } \\
\hline $3^{\text {rd }}$ period & $9(23,1 \%)$ & $6(18,8 \%)$ & \\
\hline | stgrade at fundamental & $3(7,7 \%)$ & $2(6,2 \%)$ & \\
\hline $2^{\text {nd }}$ grade & $2(5,1 \%)$ & $3(9,4 \%)$ & \\
\hline $3^{\text {rd grade }}$ & $3(7,7 \%)$ & $2(6,2 \%)$ & \\
\hline $4^{\text {th }}$ grade & $2(5,1 \%)$ & $5(\mid 5,6 \%)$ & \\
\hline $5^{\text {th }}$ grade & $6(15,4 \%)$ & $5(15,6 \%)$ & \\
\hline $6^{\text {th }}$ grade & $0(0,0 \%)$ & $2(6,2 \%)$ & \\
\hline$>7^{\text {th }}$ grade & $3(7,7 \%)$ & $5(15,6 \%)$ & \\
\hline Shift: & | $8(46,2 \%)$ & $13(40,6 \%)$ & 0,025 \\
\hline \multicolumn{4}{|l|}{ Morning } \\
\hline Afternoon & $13(33,3 \%)$ & $19(59,4 \%)$ & \\
\hline Scholar problems? & $6(15,4 \%)$ & $3(9,4 \%)$ & 0,186 \\
\hline Practice sport? & | $6(41,0 \%)$ & $21(65,6 \%)$ & 0,059 \\
\hline Atopy: & $18(46,2 \%)$ & | $4(43,8 \%)$ & 0,129 \\
\hline \multicolumn{4}{|l|}{ Itchy eyes? } \\
\hline Have you ever wheezed? & $19(48,7 \%)$ & $8(25 \%)$ & 0,066 \\
\hline Still wheeze? & $7(17,9 \%)$ & $0(0 \%)$ & 0,008 \\
\hline
\end{tabular}

Table 2. Field scores and pattern deviation in groups case (oral breathers) and control (non oral breathers).

\begin{tabular}{lccc}
\hline Field & Cases & Control & $p$ \\
\hline Nasal problem & $27,2 \mid(+-5,09)$ & $\mid 4,63(+-5,80)$ & $<0,000 \mid$ \\
Sleep & $30,13(+-7,008)$ & $\mid 7,09(+-6,244)$ & $<0,000 \mid$ \\
Eating & $18,49(+-4,47 \mid)$ & $\mid 4,16(+-3,903)$ & $<0,000 \mid$ \\
Odontology & $7,66(+-3,290)$ & $7,22(+-3,925)$ & $0,6 \mid 2$ \\
Education & $7,42(+-2,94 I)$ & $6,9 \mid(+-3,796)$ & 0,535 \\
Communication & $5,92(+-2,329)$ & $4,31(+-1,99 \mid)$ & 0,003 \\
Atopy & $15,36(+-5,807)$ & $10,59(+-3,680)$ & $<0,000 \mid$ \\
\hline Total & $\mid 13,35(+-18,627)$ & $74,9 \mid(+-20,04)$ & $<0,000 \mid$ \\
\hline
\end{tabular}

The third field with greater scoring was related to eating. The group of oral breathers presented a prevalence of problems with nutrition three times greater than the control group while, in study of Ribeiro (1) this prevalence in oral breatherswas of $42,5 \%$. Studies show an existing relation between oral breather and presence of change in deglutition and mastication pattern. This way, Junqueira et al (26) described a frequency of $88,5 \%$ to changes in masticatory function andof $78,1 \%$ to changes in deglutition pattern; Coelho (27) found a frequency of 
$40 \%$ to masticatory change and of $80 \%$ to change in deglutition pattern, in patients with adenotonsillar hypertrophy.

Some articles $(22,28,29)$ demonstrated that allergic rhinitis is evidenced as the etiologic main factor of oral breathing $(22,28,29)$, agreeing with this present study in field of nasal problems presented a higher scoring of repercussion in quality of life of oral breather adding the presence of atopy (fourth greater score), field in which is included allergic rhinitis as important etiologic factor.

In oral breathers, the chance in finding an asthmatic individual was almost eight times greater than in control group (OR=7,72; IC 95\%: 0,85 - 177,31; pFisher=0,056). This increased prevalence of asthma in oral breathers was already described in literature $(1,4)$. This may be due to the fact of that there is a contiguous relation between upper and lower respiratory tract, beyond a higher prevalence of atopy in oral breathers. This way, the oral breathing allows the allergens or the irritant agents reach the lower airways, causing bronchial hyperresponsiveness and asthma induced by exercise. The asthma association and allergic rhinitis are of such importance that some authors prefer to use term "united airways disease" (30). Other studies had already described association between snoring and asthma, and oral breathing fits in this environment of pathophysiological chain, once that the first is one of the most predictive signs to diagnosis based on anamnesis, and the second is strongly associated to Oral Breather Syndrome. In present study, the oral breather patients presented prevalence of nocturnal snoring in $87,2 \%$, setting a risk 27 times greater of snores when compared to controls. Lu (31)studying the prevalence of snore in preschoolers showed that this was of $10,5 \%$ to both genders and that snore is significantly associated to nocturnal cough and asthma. AYDANUR (32) also observed relation between respiratory disturbs in sleep and symptoms related to asthma in his study involving adults, in Turkey, once more, the close relationship between upper and lower airways (33).

Related to the Odontology Field, the scoring were lower, showing that these factors seem not leading to greater repercussion in quality of life of this group or maybe occur in lower perception of orthodontic changes, taking regard to low age average of this sample, despite of finding important orthodontic changes and craniofacial changes in oral breathers. The literature shows that there is no direct relation between signs and symptoms of these disorders and its repercussions over Quality of Life $(24,34,35)$.

This way, the Educational Field also presented low scores, which disagree with data found in literature, where it was found an association between the presence of oral breather Syndrome with bad educational performance $(21,36)$.

Evaluating quality of life in children presented as a challenge, by the fact, in some situations, third parties answered to the questionnaire, which leads to decrease the precision of the answers. However, the literature indicates that the evaluation of quality of life related to the health of child must include information from the perspective of patients and their caregivers, who despite of being different are equally important (34) and complement each other.

\section{CONCLUSION}

With this study, we can conclude that the Oral Breather Syndrome seem to be related to an impact in quality of life, especially in which it refers to nasal problems, sleep and eating. Although, future studies, applying the same questionnaire will become necessary in order to it become an instrument capable to evaluate the quality of life of oral breather patients.

\section{Biblographic ReFERENCES}

1. Ribeiro ML, Pinto JA. Qualidade de vida no respirador oral: avaliação sistemática em crianças de 6 a 12 anos, atendidas em centro de referência da UFMG. [dissertação]. Minas Gerais: Universidade Federal de Minas Gerais; 2006.

2. Eiser C, Morse R. The measurement of quality of life in children: past and future perspectives. Developmental and Behavioral Pediatrics. 2001, 22(4):248-55.

3. Carr AJ, Gibson B, Robinson PG. Is quality of life determined by expectations or experience? BMJ. 2001, 322:1240-3.

4. Abreu RR, Rocha RL, LamounierJA, Guerra AFM. Etiology, clinical manifestations and concurrent findings in mouthbreathing children. J. Pediatr. [serial online] 2008 Dec [citado 2009 Oct 13]; 84(6): 529-35. Encontrado em: URL: http:/ /www.scielo.br/pdf/jped/v84n6/v84n6a10.pdf

5. Abreu RR, Rocha RL, Lamounier JA, Guerra AFM. Prevalence of mouth breathing among children. J Pediatr. 2008, 84(5).

6. Campanha SMA, Lincoln MSF, Fontes MJF. O impacto da asma, da rinite alérgica e da respiração oral na qualidade de vida de crianças e adolescentes. Rev CEFAC. 2008, 10(4):513-19.

7. Cunha DA, Silva GAP, Motta MEFA, Lima CR, Silva HJ. A 
respiração oral em crianças e suas repercussões no estado nutricional. Rev CEFAC. 2007, 9(1):47-54.

8. Menezes VA, Leal RB, Pessoa RS, Pontes RMS. Prevalence and factors related to mouth breathing in school children at the Santo Amaro project-Recife. Rev Bras Otorrinolaringol. 2005, 72(3):394-99.

9. Tavares JG, Silva EHAA. Considerações teóricas sobre a relação entre respiração oral e disfonia. Rev Soc Bras Fonoaudiol. 2008, 13(4):405-10.

10. Lemos CM, Wilhelmsen NSW, Mion OG, Mello JFJ. Alterações funcionais do sistema estomatognático em pacientes com rinite alérgica: estudo caso-controle. BrazJ Otorhinolaryngol. 2009, 75(2):268-74.

11. Bluestone C. Pediatric Otolaryngology, $2^{\text {nd }}$ ed. WB Saunders Company; 1990.

12. Becker HMG, Guimarães RES, Pinto JA, Vasconcellos MC. Respirador bucal. Em: LeãoE, Correa EJ, Mota JAC, Viana MB. Pediatria ambulatorial. $4^{\text {nd }}$ ed. Belo Horizonte: Ed Coopmed; 2005. p. 487-93.

13. Francesco RCD, Passerotti G, Paulucci B, Miniti A. Mouth breathing in children: different repercussions according to the diagnosis. Rev Bras Otorrinolaringol. 2004, 70(5).

14. Becker HMG, Guimarães RES, Pinto JA, Vasconcellos MC. Respirador bucal. Em: Leão E, Correa EJ, Mota JAC, Viana MB. Pediatria ambulatorial. $4^{\text {nd }}$ ed. Belo Horizonte: Ed Coopmed; 2005. p. 487-93.

15. Rizzo MC. O respirador bucal. In: Naspitz C. Alergias respiratórias. $1^{\text {nd }}$ ed. São Paulo: Vivali; 2003.

16. Suratt PM, et al. Cognitive Function and Behavior of Children with Adenotonsilar Hypertrophy Suspected of Having Obstructive Sleep-Disordered Breathing. Pediatrics. 2006, 118:771-81.

17. Marcus CL. Sleep-disordered Breathing in Children. Am J Respir Crit Care Med. 2001, 164:16-30.

18. American Academy of Pediatrics. Clinical Practice Guideline: Diagnosis and Management of Childhood Obstructive Sleep Apnea Syndrome. Pediatrics. 2002, 109:704-12.

19. Franco RA, Rosenfeld R, Rao M. Quality of life for children with obstructive sleep apnea. Oto Head Neck Surg. 2000, 123:9-16.

20. Silva MGN, Adaptação e validação do questionário
"RQLQ" para avaliação da qualidade de vida em crianças e adolescentes com rinite alérgica. [tese]. São Paulo: Universidade Federal de São Paulo; 1999.

21. Hunt CE. Neurocognitive Outcomes in Sleep-Disordered Breathing. J Pediatrics. 2004, 145:430-32.

22. Guilleminault C, Pelayo R, Leger D, Clerk A, Bocian RCZ. Recognition of Sleep-disoredered Breathing in Children. Pediatrics. 1996, 98(5):871-882.

23. Gottlieb DJ et al. Sleep-Disordered Breathing Symtoms are Associated wit Poorer Cognitive Function in 5-Year-Old Children. J Pediatrics. 2004, 145:458-464.

24. Flemons WW, Reimer MA. Development of a Diseasespecific Health-related Quality of Life Questionaire for Sleep Apnea. Am J Rep Crit Care Med. 1998, 158:494-03.

25. Serres LM, Derkay C, Astley S, Deyo RA, Rosenfeld RM, Gates, GA. Measuring quality of life in children with obstructive sleep disorders. Arch Otolaryngol Head Neck Surg. 2000, 126(12):1423-1429.

26. Barros JRC, Becker HMG, Pinto JA. Avaliação de atopia em crianças respiradoras bucais atendidas em centro de referência. J Pediatr. 2006, 82(6):458-64

27. Rizzo C, Hauache S, Naspitz N, Pignatari S, Junqueira P, Hallinan Metal. Characteristics of children with allergic rhinitis and chronic mouth breathing. J Allergy Clin Immunol. 2002, 109(1):S263.

28. Junqueira PAS, Di Francesco RC, Trezza P, Zeratti FE, Frizzarini R, Faria MEJ. Alteracoes funcionais do sistema estomatognatico pre e pos-adenoamigdalectomia. Pro-fono. 2002, 14(1):17-22.

29. Coelho MF, Terra VHTC. Implicações clinicas em pacientes respiradores bucais. Rev Bras Patol Oral. 2004, 3(1):17-19.

30. Craig TJ, Hanks CD, Fisher LH. How do topical nasal corticosteroids improve sleep and daytime somnolence in allergic rhinitis? J Allerg Clin Immunol. 2005, 116(6):1264-6.

31. Cintra CFSC, Castro FFM, Cintra PPVC. As alterações orofaciais apresentadas em pacientes respiradores bucais. Rev Bras Aler Imunopatol. 2000, 23(2):78-83.

32. Solé D, Wandalsen GF, Camelo-Nunes IC, Naspitz CK, ISAAC - Grupo Brasileiro. Prevalência de sintomas de asma, rinite e eczemaatópico entre crianças eadolescentes brasileiros identificados pelo International Study of Asthma and Allergies (ISAAC) - Fase 3. J Pediatr. 2006, 82(5):341-46. 
33. ARIA Brasil. Manejo da rinite alérgica e seu impacto na asma - Guia de bolso. Salvador: ARIA; 2002.

34. Lu LR, Peat J, Sullivan CB. Snoring in Preschool Children : Prevalence and Association with Noctturnal Cough and Asthma. Chest. 2003, 124(2):587-93.

35. Aydanur E et al. Association of asthma-related symtoms with snorinhg and apnea and effect on heath-related quality of life. Chest. 2005, 128(5):3358-3363.

36. Bousquet J, van Cauwenberge P, Kathaltaev N. Allergic rhinitis and its impact on asthma. J Allergy Clin Immunol. 2001,108(5):S147-334.
37. Eiser C, Morse R. A review of measurements of quality of life for children with chronic illness. Arch Dis Child. 2001, 84:205-11.

38. Suratt PM, et al. Cognitive Function and Behavior of Children with Adenotonsilar Hypertrophy Suspected of Having Obstructive Sleep-Disordered Breathing. Pediatrics. 2006, 118:771-81.

39. Gozal D. Sleep-Disordered Breathing and School Performance in Children. Pediatrics. 1998, 102(3):616-20. 